\title{
Spontaneous Angiographic Regression of Cerebral Arteriovenous Malformations: Angiographic Disappearance is not the Real Cure
}

\author{
Serebral Arteriyovenöz Malformasyonlarn Spontan Anjiyografik \\ Gerilemesi: Anjiyografik Kaybolma Gerçek Tam Tedavi Değildir
}

Fumihiro MATANO, Yasuo MURAI, Shunsuke NAKAGAWA, Takeshi WADA, Takayuki KITAMURA, Akira TERAMOTO

Nippon Medical School, Department of Neurosurgery, Tokyo, Japan

Corresponding Author: Fumihiro MATANO / E-mail: s00-078@nms.ac.jp

\begin{abstract}
Angiographically occult arteriovenous malformations (AOAVMs) are poorly understood. AOAVMs include spontaneous regression of cerebral AVMs. Here we discuss spontaneous angiographical regression of cerebral arteriovenous malformations (SRAVM). We present the case of a 34-year-old male patient with SRAVM in whom an arteriovenous (AV) shunt remnant was revealed by intraoperative indocyanine green videoangiography (ICG-VAG). Preoperative angiography indicated spontaneous regression of AVM. We reviewed the literature for articles having specific citations or case histories of SRAVMs. On the basis of our ICG-VAG findings, we confirmed the possibility of an AV shunt remnant being present in patients with SRAVMs. In addition to our own case, we reviewed previously reported cases and analyzed the data from 132 patients with SRAVMs. Ninety-five (72\%) such patients received conservative therapy without surgical removal, and 37 (28\%) were treated surgically. Only three patients in whom an SRAVM recanalized after 39, 31, and 16 months have been reported. The rate of recanalization in SRAVM including 3 previously reported cases and the present case, is 3.0\% (4/132). Intraoperative ICG-VAG can reveal more SRAVMs that recanalize within a short period even if AV shunts are not depicted by angiography. Therefore, surgical removal of the AOAVM should be considered in cases with low surgical risk.
\end{abstract}

KEYWORDS: Arteriovenous malformation, Angiographically occult, Indocyanine green videoangiography, Spontaneous regression

Öz

Anjiyografik olarak gizli arteriyovenöz malformasyonlar (AOAVM'ler) iyi bilinmeyen bir durumdur. AOAVM'ler arasında serebral AVM'lerin spontan gerilemesi vardır. Burada serebral arteriyovenöz malformasyonlarda spontan anjiyografik gerilemeyi (SRAVM) tartışacağız. Bir arteriyovenöz (AV) şant kalıntısının intraoperatif indosiyanin yeşili video anjiyografisi (ICG-VAG) ile ortaya çıktığı 34 yaşında bir erkek SRAVM hastası sunuyoruz. Preoperatif anjiyografi AVM'nin spontan gerilemesine işaret etti. Literatürde spesifik SRAVM atıfları veya olgu öyküleri olan makaleleri aradık. ICG-VAG bulgularımız temelinde SRAVM hastalarında bir AV şantı kalıntısı bulunması olasılığını doğruladık. Kendi olgumuz dışında önceden bildirilen olguları gözden geçirip 132 SRAVM hastasının verilerini analiz ettik. Bu hastaların doksan beşinde (\%72) cerrahi eksizyon yapılmaksızın konservatif tedavi görürken, 37'si (\%28) cerrahi olarak tedavi edilmişti. Bir SRAVM'nin tekrar kanalize olduğu (39, 31 ve 16 ay sonra) sadece üç hasta bildirilmiştir. SRAVM'de tekrar kanalizasyon oranı daha önce bildirilen 3 olgu ve mevcut olgu dahil olmak üzere \%3,0'dır (4/132). Anjiyografi AV şantlarını göstermese bile intraoperatif ICG-VAG kısa bir süre içinde tekrar kanalize olan daha fazla SRAVM'yi ortaya koyabilir. Bu nedenle cerrahi riski düşük hastalarda AOAVM'nin cerrahi eksizyonu düşünülmelidir.

ANAHTAR SÖZCÜKLER: Arteriyovenöz malformasyon, Anjiyografik olarak gizli, İndosiyanin yeşili videoanjiyografisi, Spontan gerileme

\section{INTRODUCTION}

The spontaneous angiographic occlusion of cerebral arteriovenous malformations (AVMs) is a relatively rare occurrence. Angiographically occult AVMs (AOAVMs) occur in less than $3 \%$ of AVM cases $(33,38,43)$ and are poorly understood. AOAVMs include spontaneous regression of cerebral AVMs. In this study, the authors discuss the angiographical spontaneous regression of cerebral arteriovenous malformations (SRAVM). It has been reported that SRAVMs are more likely to occur in patients with small AVMs that present with intracerebral hemorrhage, and are fed by a single feeder artery and drained through a single vein $(11,29,32,50)$. Conservative treatment strategies without radical resection are used for many reported cases of SRAVMs $(1,3,4,7-10,13,14,16,17,19-25,27,28$, $30,34,35,40-42,44,47,49,51$ ). Abdulrauf et al. (1) suggested that neovascularization within a thrombosed AVM may lead to lesion recanalization. The management of SRAVMs has not been established. We describe the case of a 34-year-old male with SRAVM who presented with intracerebral hemorrhage. An arteriovenous (AV) shunt remnant was confirmed by intraoperative indocyanine green videoangiography (ICG-VAG) and preoperative angiography indicated spontaneous regres- 
sion of AVM. In addition, we used the key words "angiographically occult AVM" and "spontaneous angiographic occlusion of cerebral arteriovenous malformations" to perform a comprehensive MEDLINE search for pertinent articles. We also reviewed the references cited in those articles for any specific citations or case histories. The articles in English and Japanese were reviewed. We discuss the various therapeutic treatment strategies for this condition.

\section{CASE REPORT}

A 34-year-old male with an unremarkable clinical history was admitted to our hospital after the sudden-onset of a disturbance in consciousness and left hemiparesis. Computed tomography scanning revealed a right frontoparietal intracerebral hemorrhage (Figure 1A), and digital subtraction angiography revealed a right frontoparietal Spetzler-Martin grade II (46) arteriovenous malformation (AVM) (Figure 1B). A conservative therapeutic approach was employed, but hematoma expansion and the disturbance of consciousness progressed. The patient underwent surgical external decompression on the day of admission. A right frontoparietal craniotomy was performed, and following incision of the dura (Figure $2 A$ ), ICG-VAG was performed. Indocyanine green (ICG:12 mg; 25 $\mathrm{mg} / 10 \mathrm{ml}$ of distilled water) was intravenously infused via a peripheral blood vessel, followed by flushing with $10 \mathrm{ml}$ of physiological saline. We confirmed an AV shunt. (Figure 2B). We were planning a two-stage surgery at a later date so we did not resect the AVM nidus or treat the $\mathrm{ICH}$; we only performed external decompression. A second digital subtraction angiography was performed on day 19 of the hospitalization to obtain a secondary preoperative angiographic evaluation. However, no AVM was identified (Figure 1C). By this time, the intracranial pressure as observed on CT had sufficiently decreased because of the surgical decompression; furthermore, brain edema had improved without the use of osmolar diuretics. Surgical removal of the hematoma followed by cranioplasty was initiated on day 21 of hospitalization. A scalp incision was made over the right frontoparietal region, followed by incision of the dura (Figure 2C). ICG-VAG was performed to confirm the presence of the AV shunt remnant before evacuating the hematoma. Although no arteriovenous malformation was identified on angiography, a part of the AV shunt was confirmed in late arterial phase on ICG-VAG. A part of the AV shunt was less visible, and, in spite of being connected by an artery, had slow flow (Figure 2D). The nidus was resected after the transcortical hematoma was removed and the feeder arteries were coagulated. The patient's postoperative course was uneventful, with no changes in the neurological deficits. Postoperative digital subtraction angiography revealed no residual AVM. The patient was transferred to another hospital for rehabilitation.

\section{DISCUSSION}

We showed that more SRAVMs may recanalize within a shorter period even if an AV shunt is not depicted by preoperative angiography in this report, based on of intraoperative ICGVAG. In addition, we discuss the treatment strategies of SRAVMs, from the analysis of the data from 132 reported patients with SRAVMs.

\section{Literature Review}

A total of 132 patients with SRAVMs have been reported in the literature $(1,3-11,13-25,27,28-37,39-42,44,45,47,49-$ $51)$, including our case. The results are summarized in Table I. Ninety-five (72\%) of these patients received conservative therapy without surgical removal, and 37 (28\%) patients were surgically treated $(5,6,15,18,31,36,37,39,45,49)$. In 25 of the 37 patients who underwent surgery, the initial digital subtraction angiography revealed no AVM; 25 patients were diagnosed with an intracranial mass lesion after the spontaneous disappearance of AVMs $(5,6,18,36,39,45)$. These patients underwent surgical resection for the purpose of histological evaluation, removal of the mass lesion, or controlling epilepsy. In 12 of the 37 patients that underwent surgery, initial digital subtraction angiography revealed an AVM but follow-up digital subtraction angiography did not reveal any AVM (15,

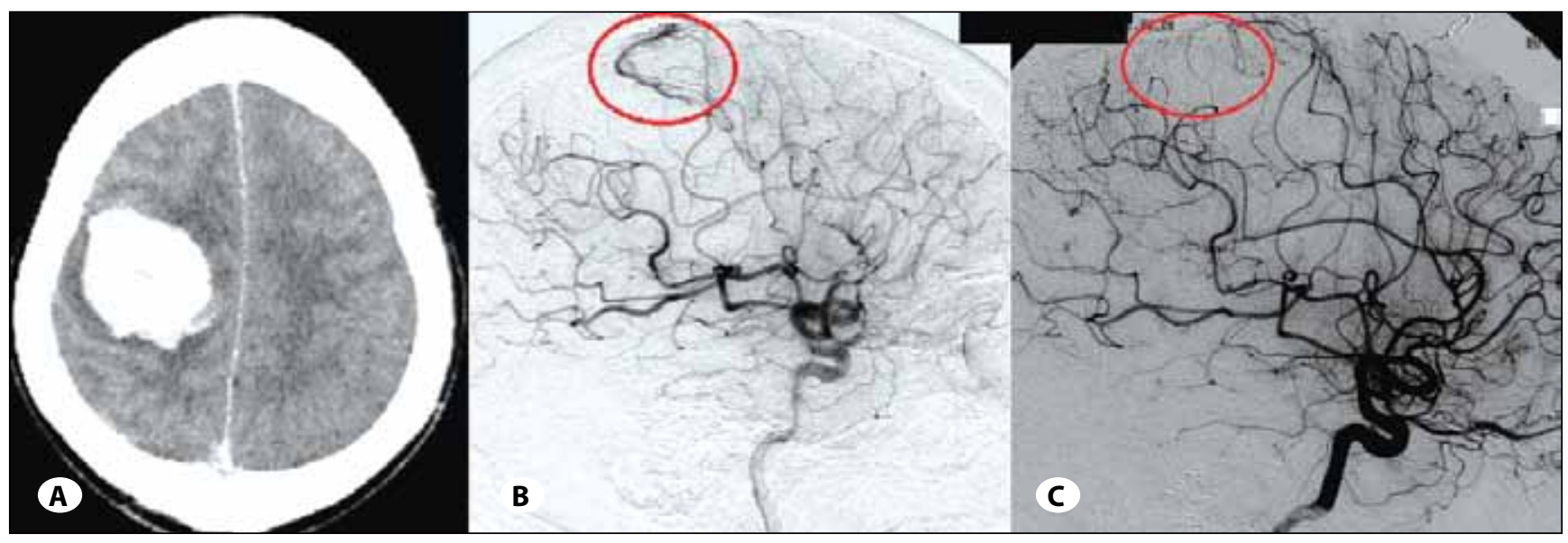

Figure 1: A) Brain computed tomography revealing an intracerebral hemorrhage in the right frontal-parietal lobe. B) Right frontoparietal AVM confirmed by cerebral angiography. C) No arteriovenous malformation is identified on the second angiography performed on day 19 of the hospitalization. 
$31,49)$, which was similar to the findings in our patient. These patients underwent surgical resection for the removal of an AVM, the removal of an AVM with hematoma, or for possible recanalization (Table II). To date, only three cases, in whom the SRAVMs recanalized after 39, 31, and 16 months have been reported $(9,35,31)$ (Table III). The rate of recanalization in SRAVM including the 3 previously reported cases and the present case is $3.0 \%(4 / 132)$.

\section{Characteristics of SRAVM}

A number of reports have addressed the clinical symptoms, treatment strategies, and factors associated with SRAVMs (7, $10,18,45,49,50,51)$. Abdulrauf et al. (1) reviewed and reported the typical characteristics of SRAVMs. They suggested that a single draining vein, hemorrhagic onset, and a size of $<6 \mathrm{~cm}$ were characteristic. Intracerebral hemorrhage, similar to that observed in our patient, occurred in $42 \%$ of SRAVMs patients (37). Hemodynamic changes resulting from intracerebral hemorrhage are considered to be the most important factors underlying the cause of SRAVMs. Moreover, a single draining vein and hemodynamic alterations in the intracranial blood flow, including intracranial hemorrhage, were observed in a majority of the patients with SRAVM (44). A mass effect caused by an intracranial hematoma may decrease blood flow in the AVM to the extent that complete thrombosis occurs in the draining vessels $(7,16,27,38)$.

\section{Indocyanine Green Videoangiography}

Reports have suggested that ICG-VAG is a useful guiding tool during the surgical treatment of AVM (48). However, to the best of our knowledge, there are no reports on intraoperative ICG-VAG performed to confirm SRAVMs.

In our present case, the AV shunt flow was confirmed by ICGVAG performed during the first decompression procedure. After the first surgery, a part of the AV shunt was thrombosed according to the mechanism mentioned above.

A second digital subtraction angiography was performed on day 19 of hospitalization, but no AVM could be identified. Meanwhile, the other part of the AV shunt remnant was confirmed by intraoperative ICG-VAG. A part of the AV shunt was less visible, and, in spite of being connected by an artery, had slow flow.

Collectively, angiography is limited by the fact that it cannot reveal the entire AV shunt in SRAVMs. Intraoperative ICG-VAG for SRAVMs is a useful guiding tool that demonstrates the part of the AV shunt that cannot be detected by angiography.
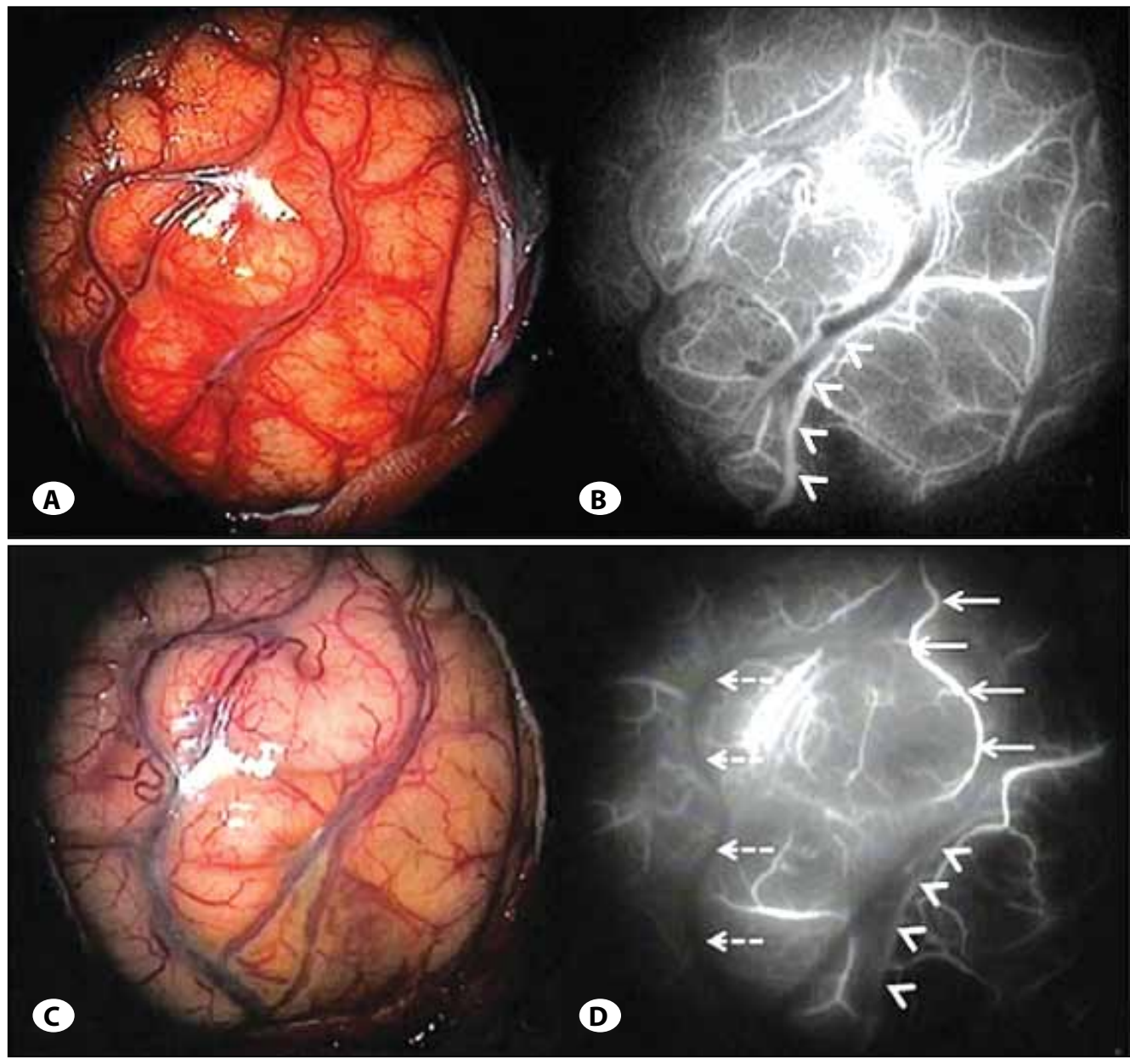

Figure 2: A) Image of the brain surface during surgery performed on admission.

B) Indocyanine green videoangiography on admission.

The AV Shunt connected by an artery is confirmed.

Arrowhead: shunt.

C) Image of the brain surface during surgery on day 21 of hospitalization. D) Late arterial phase of indocyanine green videoangiography on day 21 of hospitalization. A part of the AV shunt is confirmed despite no arteriovenous malformation identified on angiography. A part of the AV shunt is less visible and, in spite of being connected by an artery, has slow flow.

Arrow: artery, Broken arrow: vein, Arrowhead: shunt. 
Table I: Clinical Data of 132 Patients

\begin{tabular}{|c|c|c|}
\hline Sex & 60 males & 72 females \\
\hline Clinical feature & $\begin{array}{l}\text { Intracerebral hemorrhage } \\
\text { Seizure } \\
\text { Subarachnoid hemorrhage } \\
\text { Headache } \\
\text { Intraventricular hemorrhage } \\
\text { Hemiparesis } \\
\text { Transient ischemic attack } \\
\text { Asymptomatic } \\
\text { Others }\end{array}$ & $\begin{array}{l}36 \% \\
23.5 \% \\
14 \% \\
8 \% \\
6 \% \\
3 \% \\
1.5 \% \\
4 \% \\
4 \%\end{array}$ \\
\hline Location & $\begin{array}{l}\text { Frontal } \\
\text { Parietal } \\
\text { Temporal } \\
\text { Occipital } \\
\text { Cerebellar } \\
\text { Basal ganglion } \\
\text { Midbrain } \\
\text { Others }\end{array}$ & $\begin{array}{l}28 \% \\
23 \% \\
10.5 \% \\
10.5 \% \\
10.5 \% \\
9 \% \\
4 \% \\
4.5 \%\end{array}$ \\
\hline Size & $\begin{array}{l}\text { Small }(<3 \mathrm{~cm}) \\
\text { Medium }(3-6 \mathrm{~cm}) \\
\text { Large }(>6 \mathrm{~cm})\end{array}$ & $\begin{array}{r}69.8 \% \\
22.4 \% \\
7.8 \%\end{array}$ \\
\hline Number of feeders & $\begin{array}{l}\text { Single } \\
\text { Multiple }\end{array}$ & $\begin{array}{l}53 \% \\
47 \%\end{array}$ \\
\hline Number of drainers & $\begin{array}{l}\text { Single } \\
\text { Multiple }\end{array}$ & $\begin{array}{l}74 \% \\
26 \%\end{array}$ \\
\hline Interval of thrombosis & Mean 5.98 months ( 3 days -45 years) & \\
\hline The rate of recanalization & & $3.0 \%$ \\
\hline
\end{tabular}

Table II: Treatment for the 132 AOAVM Cases

- 95 cases (72\%) Conservative therapy without surgical removal

- 37 cases $(28 \%) \quad$ Surgery

- 25 cases (19\%) Diagnosed with an intracranial mass lesion after spontaneous regression of

\begin{tabular}{lll}
-12 cases $(9 \%)$ & AVM \\
\hline
\end{tabular}

Table III: Summary of Clinical Data for Recanalized Cases

\begin{tabular}{|l|c|c|c|c|c|c|c|c|} 
Series & $\begin{array}{c}\text { Age/ } \\
\text { Sex }\end{array}$ & $\begin{array}{c}\text { Clinical } \\
\text { Features }\end{array}$ & Location & Size & $\begin{array}{c}\text { Number } \\
\text { of arterial } \\
\text { feeders }\end{array}$ & $\begin{array}{c}\text { Number of } \\
\text { draining } \\
\text { veins }\end{array}$ & $\begin{array}{c}\text { Interval of } \\
\text { thrombosis }\end{array}$ & Treatment \\
\hline Castaigne, 1961 & $31 / \mathrm{F}$ & Seizure & Frontal & $\mathrm{U}$ & $\mathrm{U}$ & $\mathrm{U}$ & 39 months & surgical resection \\
\hline Nukui, 1982 & $54 / \mathrm{M}$ & $\mathrm{SAH}$ & Occipital & $\mathrm{S}$ & $\mathrm{S}$ & $\mathrm{S}$ & 120 months & surgical resection \\
\hline Mizutani, 1995 & $59 / \mathrm{F}$ & $\mathrm{SAH}$ & Frontal & $\mathrm{S}$ & $\mathrm{M}$ & $\mathrm{S}$ & 1.5 months & surgical resection \\
\hline Present case & $34 / \mathrm{M}$ & $\mathrm{ICH}$ & Frontal & $\mathrm{S}$ & $\mathrm{S}$ & $\mathrm{S}$ & 19 days & surgical resection \\
\hline
\end{tabular}




\section{Follow-up in SRAVM Cases}

From the reported cases, a follow-up of recanalization for at least 2-5 years is considered necessary $(2,23,26,28,34$, 51,52 ). Mizutani et al. (31) reported a patient in whom an SRAVM completely recanalized as revealed by angiography 31 months after complete spontaneous thrombosis. Panciani et al. (37) reported that the mean time from diagnosis of SRAVMs to complete spontaneous regression was 54 months and that the occlusion can persist for 7 years after thrombosis. In total, $97 \%$ of the reported patients with SRAVMs showed no recanalization or rebleeding. However, the remaining $3 \%$ of the reported patients with AOAVM recanalization should be considered and close follow-up of SRAVMs is recommended.

\section{Surgical Removal}

The AVM shunt remnant was confirmed by ICG-VAG during the second surgery in our patient. The findings from our case study indicate that there is a possibility of a small AV shunt remnant being present in patients with SRAVMs. Thrombosis does not entirely account for the histological presence of angiographically occult lesions, because SRAVMs with AV shunts are dangerous lesions (12). Meanwhile, complete removal of SRAVMs is reported to be relatively straightforward compared with the usual AVMs $(8,11,14,36,43)$. Surgical removal of SRAVMs is therefore recommended in easy and low-risk cases.

\section{CONCLUSION}

Intraoperative ICG-VAG can reveal more SRAVMs that recanalize within a short period even if AV shunts are not depicted by angiography. Surgical removal of an AOAVM should therefore be considered in cases with low surgical risk.

\section{REFERENCES}

1. Abdulrauf SI, Malik GM, Awad IA: Spontaneous angiographic obliteration of cerebral arteriovenous malformation. Neurosurgery 44: 280-287, 1999

2. Ali MJ, Bendok BR, Rosenblatt S: Recurrence of pediatric cerebral arteriovenous malformations after angiographically documented resection. Pediatr Neurosurg 39: 32-38,2003

3. Auzou P, Callonnec F, Hannequin D: Spontaneous thrombosis of cerebral arteriovenous malformation. J Radiol 78: 219-222,1997

4. Barker CS, Anslow PL: Spontaneous thrombosis of a cerebral arteriovenous malformation. Clin Radiol 42: 130-132, 1990

5. Becker DH, Townsend JJ, Kramaer RA: Occult cerebrovascular malformations. Series of 18 histologically verified cases with negative angiography. Brain 102: 249-287,1979

6. Bell $B A$, Kebdall $B E$, Symon L: Angiographically occult arteriovenous malformations of the brain. J Neurol Neurosurg Psychiat 41: 1057-1064,1978

7. Buis DR, van den Berg R, Lycklama G: Spontaneous regression of brain arteriovenous malformations--a clinical study and a systematic review of the literature. J Neurol 251:13751382,2004
8. Carter BS, Brisman JL, Ogilvy CS: Spontaneous obliteration of an arteriovenous malformation associated with head trauma. Case illustration. J Neurosurg 94: 139,2001

9. Castaigne $P$, Buge A, Pertuiset B: Angiome thrombose, radiologiquement exclu. Bull Soc Med Hop Paris 77:923930,1961

10. Cloft HJ: Spontaneous regression of cerebral arteriovenous malformation in hereditary hemorrhagic telangiectasia. AJNR Am J Neuroradiol 23:1049-1050, 2002

11. Conforti P: Spontaneous disappearance of cerebral arteriovenous angioma. Case report. J Neurosurg 34: 432-434,1971

12. Dennis R, Lycklama G, Bart H: Spontaneous regression of brain arteriovenous malformations. A clinical study and a systematic review off the literature. J Neurol 251: 1375-1382,2004

13. Dyck P: Spontaneous thrombosis of an arteriovenous malformation. Neurosurgery 1:287-290,1977

14. Eisenman Jl, Alekoumbides A, Pribram H: Spontaneous thrombosis of vascular malformations of the brain. Acta Radiol Diagn (Stockh) 13:77-85,1972

15. Enam S, Malik G: Association of cerebral arteriovenous malformations and spontaneous occlusion of major feeding arteries: Clinical and therapeutic implications. Neurosurgery 45: 1105-1111,1999

16. Ezura M, Kagawa S: Spontaneous disappearance of huge cerebral arteriovenous malformation: Case report. Neurosurgery 30: 595-599,1992

17. Gibb PA, Gullan RW, Sandhu N: Spontaneous angiographic disappearance of an intracranial arteriovenous malformation. Br J Neurosurg 2: 529-533,1988

18. Golden JB, Kramer RA: The angiographically occult cerebrovascular malformation. Report of three cases. J Neurosurg 48: 292-296, 1978

19. Guazzo EP, Xuereb JH: Spontaneous thrombosis of an arteriovenous malformation. J Neurol Neurosurg Psychiatry 57: 1410-1412,1994

20. Hamada J, Yonekawa Y: Spontaneous disappearance of a cerebral arteriovenous malformation: Case report. Neurosurgery 34: 171-173,1994

21. Heeres JG, Hekster RE, Thomeer RA: Spontaneous thrombosis of arteriovenous malformation in cerebral vessels, 10 years after manifestation of lesion. Ned Tijdschr Geneeskd 10: 5761,1976

22. Hook O, Johanson C: Intracranial arteriovenous aneurysms; a follow-up study with particular attention to their growth. AMA Arch Neurol Psychiatry 80: 39-54,1958

23. Krapf H, Siekmann R, Freudenstein D: Spontaneous occlusion of cerebral arteriovenous malformation: Angiography and MR Imaging follow up and review of the literature. AJNR Am J Neuroradiol 22: 1556-1560,2001

24. Kushner J, Alexander Jr E: Partial spontaneous regression arteriovenous malformation; case report with angiographic evidence. J Neurosurg 32: 360-366, 1970

25. Leramo OB, Clarke WF: Complete spontaneous regression of a cerebral arteriovenous malformation. South Med J 80: 529532,1978 
26. Lindqvist M, Karlsson B, Guo WY: Angiographic long-term follow-up data for arteriovenous malformations previously proven to be obliterated after gamma knife radiosurgery. Neurosurgery 46: 803-810, 2000

27. Mabe $\mathrm{H}$, Furuse M: Spontaneous disappearance of a cerebral arteriovenous malformation in infancy. Case report. J Neurosurg 46: 811-815,1997

28. Megison P, Batjer HH, Purdy PD: Spontaneous resolution of arteriovenous malformation without hemorrhage. AJNR Am J Neuroradiol 10: 204, 1989

29. Minakawa T, Tanaka R, Koike T: Angiographic follow-up study of cerebral arteriovenous malformations with reference to their enlargement and regression. Neurosurgery 24:6874,1989

30. Miyazaki M, Shima T, Yokoyama N: Spontaneous and postirradiation complete regression of arteriovenous malformations (AVM) of the brain proved by angiography. No Shinkei Geka 6: 195-203,1978

31. Mizutani T, Tanaka H, Aruga T: Total recanalization of a spontaneously thrombosed arteriovenous malformation. Case report. J Neurosurg 82: 506-508,1995

32. Mojola MF, Fox AJ, Vinuela FV: Spontaneous regression of intracranial arteriovenous malformations. Report of three cases. J Neurosurg 57: 818-822,1982

33. Nehls DG, Pittman HW: Spontaneous regression of arteriovenous malformations. Neurosurgery 11: 776-780,1982

34. Norlen G: Arteriovenous aneurysms of the brain; report of ten cases of total removal of the lesion. J Neurosurg 6: 475-494,1949

35. Nukui H, Miyagi O, Tamada J: Long-term follow-up study by cerebral angiography in cases with arteriovenous malformation of the brain. With special reference to spontaneous disappearance of arteriovenous malformation in cerebral angiography (author's transl). Neurol Med Chir (Tokyo) 22: 125-132, 1982

36. Ohara S, Umemura S, Wakabayashi S: Totally thrombosed large arteriovenous malformation a case report. No Shinkei Geka 10: 1233-1237,1982

37. Panciani PP, Fontanella M, Carlino C: Progressive spontaneous occlusion of a cerebellar AVM: Pathogenetic hypothesis and review of literature. Clin Neurol Neurosurg 110: 502-510, 2008

38. Pasqualin A, Vivenza C, Rosta L: Spontaneous disappearance of intracranial arterio-venous malformations. Acta Neurochir (Wien) 76: 50-57, 1985
39. Patel MC, Hodgson TJ, Kemeny AA: Spontaneous obliteration of pial arteriovenous malformations: A review of 27 cases. AJNR Am J Neuroradiol 22: 531-536, 2001

40. Salpietro FM, Cipri S, Tomasello F: Late onset of a large cavernous aneurysm after spontaneous disappearance of cerebral arteriovenous malformation. Case report. J Neurosurg Sci 33: 211-214, 1989

41. Sartor K: Spontaneous closure of cerebral arteriovenous malformation demonstrated by angiography and computed tomography. Neuroradiology 15: 95-98,1978

42. Sasaki U, Itagaki T, Shimizu H: Almost complete regression of cerebral arteriovenous malformation: Report of a case. No Shinkei Geka 4: 175-181,1976

43. Sawlani V, Handique A, Phadke RV: Spontaneous regression of cerebral AVM due to thrombosis of draining vein-angiographic and MRI demonstration. J Neurol Sci 223: 195-198,2004

44. Schwartz ED, Hurst RW, Sinson G: Complete regression of intracranial arteriovenous malformations. Surg Neurol 58: 139-147, 2002

45. Scott BB, Seeger JF, Schneider RC: Successful evacuation of a pontine hematoma secondary to rupture of a pathologically diagnosed "cryptic" vascular malformation. Case report. J Neurosurg 39: 104-108, 1973

46. Spetzler RF, Martin NA: A proposed grading system for arteriovenous malformations. J Neurosurg 65: 476-483, 1986

47. Sukoff MH, Barth B, Moran T: Spontaneous occlusion of a massive arteriovenous malformation: case report. Neuroradiology 4: 121-123, 1972

48. Takagi Y, Sawamura K, Hashimoto N: Evaluation of serial intraoperative surgical microscope-integrated intraoperative near-infrared indocyanine green videoangiography in patients with cerebral arteriovenous malformations. Neurosurgery 70: 34-42, 2012

49. Takano S, Nose T, Maki Y: Spontaneous occlusion of a cerebral arteriovenous malformation: report of a case. No Shinkei Geka 15: 991-996, 1987

50. Wakai S, Chen CH, Wu KY: Spontaneous regression of cerebral arteriovenous malformation. Report of a case and review of the literature. Arch Neurol 40: 377-380, 1983

51. Watanabe $H$, Nakamura $H$, Matsuo $Y$ : Spontaneous regression of cerebral arterio-venous malformation following major artery thrombosis proximal to dominant feeders: A case report. No Shinkei Geka 23: 371-376, 1995

52. Weil AG, Li S, Zhao JZ: Recurrence of a cerebral arteriovenous malformation following complete surgical resection: A case report and review of the literature. Surg Neurol Int 2: 175, 2011 